\title{
Pemilihan Masker Standar Pencegahan Penularan Covid-19 di Kelurahan Talang Banjar
}

\author{
Iin Indrawati ${ }^{1}$, Faridah $^{2}$ \\ ${ }^{1}$ Progaram Studi D III Keperawatan, STIKes. Baiturrahim Jambi \\ ${ }^{2}$ Progaram Studi D III Fisioterapi, STIKes. Baiturrahim Jambi \\ Email: iinian737497@gmail.com
}

Submitted : 26/05/2021

Accepted: 02/06/2021

Published: 28/06/2021

\begin{abstract}
In Indonesia, currently they are still fighting the Corona / Covid 19 Virus, as well as in other countries. The number of cases affected by patients continues to grow. In several reports reported recovery, but not a few who died. Information dissemination aims to change people's attitudes, beliefs and behavior through providing information and raising awareness that a problem that arises can be overcome, especially in terms of preventing the transmission of Covid 19 through the selection and use of good and correct masks. Providing correct knowledge to the public can be done in various ways, one of which is by directly socializing the knowledge that will be given. This community service activity is carried out by extension methods, distributing information brochures, distributing masks and directly teaching the community how to use masks and choosing the right and good masks.After health education was carried out, the community understood and wanted to choose masks and use masks correctly. The public also understands the importance of taking preventive measures so as not to be infected or exposed to the Covid 19 virus. Health education activities should be carried out routinely by health workers in order to improve public health by changing people's life habits to be clean and healthy ones
\end{abstract}

Keywords: covid-19, masks

Abstrak
Di Indonesia saat ini masih melawan Virus Corona/Covid 19, begitupun dengan negara lain. Jumlah kasus pasien yang terkena terus bertambah. Pada laporan beberapa melaporkan kesembuhan, tapi tidak sedikit yang meninggal. Desiminasi informasi bertujuan mengubah sikap, keyakinan dan prilaku masyarakat melalui pemberian informasi serta memunculkan kesadaran bahwa suatu masalah yang timbul dapat diatasi, khususnya dalam hal pencegahan penularan Covid 19 melalui pemilihan dan penggunaan masker yang baik dan benar.Memberikan pengetahuan yang benar kepada masyarakat bisa dengan berbagai cara, salah satunya yaitu dengan melakukan sosialisasi secara langsung terhadap pengetahuan yang akan diberikan. Kegiatan pengabdian masyarakat ini dilakukan dengan metode penyuluhan, membagikan brosur materi penyuluhan, dan membagiakn masker serta mengajari secara langsung masyarakat cara menggunakan masker dan memilih masker yang benar dan baik.Setelah dilakukan pendidikan kesehatan, masyarakat memahami dan berkeinginan untuk memilih masker dan menggunakan masker dengan benar. Masyarakat juga memahami tentang pentingnya melakukan tindakan pencegahan agar tidak tertular atau terkena virus covid 19. Kegiatan pendidikan kesehatan ini sebaiknya dilakukan secara rutin oleh petugas kesehatan agar dapat meningkatkan kesehatan masyarakat dengan merubah prilaku hidup masyarakat menjadi prilaku hidup bersih dan sehat.

Kata Kunci : covid-19, masker 


\section{PENDAHULUAN}

Virus Corona adalah bagian dari keluarga virus yang menyebabkan penyakit pada hewan ataupun juga pada manusia. Di Indonesia, masih melawan Virus Corona hingga saatini, begitupun juga di negaranegara lain. Jumlah kasus Virus Corona terus bertambah dengan beberapa melaporkan kesembuhan, tapi tidak sedikit yang meninggal. Usaha penanganan dan pencegahan terus dilakukan demi melawan COVID-19 dengan gejala mirip Flu. Kasusnya dimulai dengan pneumonia atau radang paru-paru misterius pada Desember 2019. Kasus infeksi pneumonia misterius ini memang banyak ditemukan dipasar hewan tersebut. Virus Corona atau COVID-19 diduga dibawa kelelawar dan hewan lain yang dimakan manusia hingga terjadi penularan. Corona virus sebetulnya tidak asing dalam dunia kesehatan hewan, tapi hanya beberapa jenis yang mampu menginfeksi manusia hingga menjadi penyakit radang paru.

Kasus ini diduga berkaitan dengan pasar hewan Huanan di Wuhan yang menjual berbagai jenis daging binatang, termasuk yang tidak biasa dikonsumsi seperti ular, kelelawar, dan berbagai jenis tikus. Dengan latar belakang tersebut, Virus Corona bukan kali ini saja memuat warga dunia panik. Memiliki gejala yang sama-sama mirip Flu, Virus Corona berkembang cepat hingga mengakibatkan infeks yang lebih parah dan gagal organ.

Salah satu bentuk dari desiminasi informasi adalah pendidikan kesehatan. Pendidikan kesehatan adalah suatu kegiatan dalam rangka upaya promotif dan preventif dengan melakukan penyebaran informasi dan meningkatkan motivasi masyarakat untuk berprilaku sehat (Stanhope \& Lancaster, 2016). Pendidkan kesehatan pada umumnya bertujuan meningkatkan kesejahteraan, dan mengurangi ketidakmampuan dan merupakan upaya untuk mengaktualisasikan potensi kesehatan dari individu, keluarga, komunitas dan masyarakat. Desiminasi informasi bertujuan mengubah sikap, keyakinan dan prilaku masyarakat melalui pemberian informasi serta memunculkan kesadaran bahwa suatu masalah yang timbul dapat diatasi. Pengetahuan yang baik dapat membantu mendorong seseorang agar mengurangi faktor resiko dan mengadopsi gaya hidup sehat.

Pengetahuan adalah segala apa yang diketahui berdasarkan pengalaman yang didapatkan oleh setiap manusia. Pada dasarnya pengetahuan akan bertambah terus dan bervariatif dengan proses pengalaman manusia yang dialami. Menurut Bunner, proses pengetahuan tersebut melibatkan tiga aspek, yaitu proses mendapatkan informasi, proses transformasi, dan proses evaluasi. Informasi baru yang didapat merupakan pengganti pengetahuan yang telah diperoleh sebelumnya adalah proses memanipulasi pengetahuan agar sesuai dengan tugas-tugas baru. Pengetahuan merupakan hasil mengingat sesuatu hal, termasuk mengingat kembali kejadian yang pernah dialami baik secara sengaja maupun tidak disengaja dan ini terjadi setelah orang melakukan kontak atau pengamatan terhadap suatu objek tertentu. Pengetahuan yang baik dan benar haruslah ditanamkan dan dipahami oleh setiap individu mulai dari anak, remaja, dewasa dan bahkan lansia agar dapat terbentuk sikap dan prilaku yang juga baik dan benar.

Memberikan pengetahuan yang benar kepada masyarakat bisa dengan berbagai cara, salah satunya yaitu dengan melakukan sosialisasi secara langsung terhadap pengetahuan yang akan diberikan. Sosialisasi yang diberikan dapat berupa penjelasan, demonstrasi, mengenalkan produk dan banyak hal lainnya. Masyarakat pada umumnya sulit untuk menerima pengetahuan jika pengetahuan hanya dilakukan dengan memberikan penjelasan saja, jadi harus diperkenalkan dengan tindakan nyata yang dapat menyentuh emosinya.

Salah satu tindakan yang dipilih dalam meningkatkan pengetahuan 
masyarakat pada kondisi pandemi Coovid-19 saat ini adalah memberi pengetahuan tentang pencegahan penularan penyakit ini. Tindakan yang dipilih oleh tim pengabdian kepada masyarakat ini adalah mensosialisasikan tentang pemilihan masker yang tepat dalam mencegah penyakit Covid-19 ini.

\section{TARGET DAN LUARAN}

Kegiatan pengabdian ini memiliki target dan luaran khusus yaitu :

\section{Target}

Target khusus yang dicapai pada kegiatan ini yaitu :

a. Masyarakat dapat menerapkan prilaku yang benar dalam penerapan 3 M pencegahan covid 19 ( mencuci tangan pakai sabun, memakai masker dan menjaga jarak).

b. Masyarakat dapat memilih masker yang paling bisa digunakan untuk mencegah masuknya virus covid 19 ke saluran pernafasan.

c. Masyarakat mampu menggunakan masker dengan cara yang benar.

d. Masyarakat menjadi fokus utama kegiatan tenaga kesehatan sebagai perpanjangan tangan tim gugus tugas covid 19 dalam kegiatan pencegahan covid 19 agar dapat memutus rantai penularan.

e. Dosen sebagai bagian dari tim kesehatan menunujukkan perannya dan keperduliannya untuk meningkatkan kesehatan masyarakat dalam merubah prilakunya menjadi lebih baik.

\section{Luaran}

Luaran kegiatan ini secara khusus yaitu:

Prilaku masyarakat dalam tindakan pencegahan covid 19 dengan menerapkan $3 \mathrm{M}$ ( Mencuci tangan pakai sabun, memakai masker, dan menjaga jarak).

a. Masyarakat mampu memilih masker yang tepat untuk dapat mencegah penularan covid 19. b. Masyarakat dapat menggunakan masker secara benar.

c. Brosur penyuluhan cara pemilihan dan penggunaan masker yang baik dan benar.

\section{METODE PELAKSANAAN}

\section{Waktu dan Tempat}

Kegiatan ini dilakukan dalam kurun waktu 6 bulan yang dimulai pada bulan September 2020 dan berakhir pada bulan Februari 2021, bertempat di Kantor Lurah Kelurahan Talang Banjar Kota jambi.

\section{Tujuan}

Tujuan dari kegiatan ini yaitu mengubah sikap, keyakinan dan prilaku masyarakat melalui pemberian informasi serta memunculkan kesadaran bahwa suatu masalah yang timbul dapat diatasi, khususnya dalam hal pencegahan penularan Covid 19 melalui pemilihan dan penggunaan masker yang baik dan benar.

\section{Sasaran}

Sasaran dalam kegiatan ini adalah masyarakat yang tinggal di wilayah Kelurahan Talang Banjar Kota Jambi.

\section{Kontribusi Peserta}

Mengikuti kegiatan dalam bentuk ceramah tatap muka langsung, pemberian contoh pemilihan masker yang baik untuk mencegah penularan penyakit Covid 19, demonstrasi penggunaan masker secara benar, Membagikan masker yang baik dan benar untuk pencegahan dan penularan penyakit Covid 19 secara gratis kepada masyarakat yang menghadiri kegiatan saat itu.

\section{Pelaksanaan Kegiatan Pengabdian}

Tahapan pelaksanaan kegiatan pengabdian ini yaitu:

a. Kegiatan awal

1) Melakukan pendekatan dengan pihak Kelurahan khususnya bidang pengendalian pencegahan penyebaran Covid 19 untuk 
menyampaikan

memberikan

kesehatan pada masyarakat tentang pemilihan dan penggunaan masker yang baik dan benar dalam mencegah penyakit Covid 19.

2) Meminta izin pada pihak Kelurahan Talang Banjar untuk memberikan pendidikan kesehatan tentang pemilihaan dan penggunaan masker yang baik dan benar untuk pencegahan penyakit Covid 19.

b. Tahap pelaksanaan

Melakukan kegiatan pendidikan kesehatan langsung ke masyarakat dengan cara ceramah, model peraga, dan demonstrasi penggunaan masker yang baik dan benar tentang masker sebagai media pencegahan penyakit Covid 19.

c. Evaluasi

Memberikanpertanyaanlisan serta melihat reaksi dari para peserta terhadap materi pendidikan kesehatan yang disampaikan.

\section{HASIL DAN PEMBAHASAN}

Hasil

a. Kegiatan yang dilakukan yaitu berupa sosialisasi tentang pemilihan dan penggunaan masker yang baik dan benar untuk mencegah masunya virus penyebab penyakit covid 19, dengan cara bertatap muka langsung dengan masyarakat namun tetap mengikuti protokol keseshatan pencegahan covid 19.

b. Sosialisasi dilakukan dengan cara penyuluhan atau memberikan pendidikan kesehatan prilaku yang benar untuk mencegah penularan covid dengan memilih dan menggunakan masker yang baik dan benar.

c. Penyebaran brosur, menunjukkan beberapa jenis masker yang dapat mencegah covid 19 dan cara penggunaannya.

d. Masyarakat menyambut baik program sosialisasi ini dan berharap program pendidikan kesehatan pada masyarakat ini dapat dibuat berkelanjutan sesuai dengan masalahmasalah kesehatan yang ada di masyarakat.

\section{Pembahasan}

Kegiatan pengabdian kepada masyarakat ini telah diatur dalam bentuk pendidikan kesehatan dengan teknik penyuluhan, demonstrasi jenis-jenis masker dan cara penggunaannya, pemberian brosur yang berisi materi tentang pemilihan dan penggunaan masker yang baik dan benar untuk mencegah covid 19.

Pendidikan kesehatan yang dilakukan dengan teknik penyuluhan dalam kegiatan pengabdian masyarakat saat ini di tujukan pada masyarakat Kelurahan Talang Banjar, hal ini dilakukan dengan alasan bahwa wilayah kelurahan Talang Banjar memiliki beberapa fasilitas umum yang memiliki potensi terjadinya kerumunan orang yang berisiko untuk terjadi penularan covid 19 secara masal. Salah satu diantaranya yang paling beriko adalah Pasar Tradisional Talang Banjar. Pasar ini berada di jalan raya utama kelurahan Talang Banjar yang akan dilalui oleh banyak orang dari luar wilayah kelurahan Talang Banjar karna merupakan jalan lintas yang bisa mengarah ke banyak tempat. Transaksi jual beli di pasar tradisional Talang banjar seringkali terlihat tidak mengindahkan prinsip pencegahan covid 19 yaitu tindakan 3 M ( mencuci tangan dengan sabun, memakai masker dan menjaga jarak ), terutama untuk tindakan memakai masker dan menjaga jarak. Hal ini seringkali dianggap oleh masyarakat sebagai hal biasa yang tidak terlalu penting untuk dilakukan. Sebagian dari masyarakat yang datang ke pasar tidak menggunakan masker dan menjaga jarak. Para pedagang sebagian besar tidak menggunakan masker, bersentuhan langsung dengan pembeli dan 
para pedagang lain. Sehingga dirasa sangat penting dilakukan tindakan langsung untuk menjelaskan, dan mengingatkan betapa berisikonya hal tersebut terhadap kesehatan mereka.

Pelaksanaan penyuluhan dilakukan secara langsung/ bertatap muka dengan masyarakat namun tetap mengikuti protokol kesehatan pencegahan covid 19 sesuai dngan aturan yang telah ditetapkan. Untuk lebih meningkatkan pengetahuan masyarakat dan juga lebih terlihat nyata dan mudah diingat serta diikuti maka tindakan yang dilakukan selain memberikan penyuluhan juga dengan membagikan brosur pada masyarakat, menunjukkan beberapa jenis masker secara langsung, mengajarkan cara memilih masker yang baik dengan menunjukkan secara langsung masker yang dibawa. Selain itu masyarakat juga diperlihatkan cara memakai masker yang baik dan benar. Masyarakat juga diminta untuk menggunakan masker yang benar dan menggunakannya dengan baik karena saat diberi penyuluhan masyarakt diberikan diberikan secarta gratis beberapa contoh masker yang dapat digunakan untuk mencegah masuknya virus covid 19.

Setiap orang harus menyadari tentang bagaimana dampak yang dapat dialami jika mereka terpapar oleh virus ini, karena gejala yang muncul bisa dimulai dari gejala yang paling ringan sampai pada gejala yang berat bahkan ada yang tidak memiliki gejala sama sekali. Sampai saat ini belum diketahui dengan pasti berapa lama COVID-19 mampu bertahan di permukaan suatu benda, meskipun studi awal menunjukkan bahwa COVID-19 dapat bertahan hingga beberapa jam, tergantung jenis permukaan, suhu, atau kelembaban lingkungan. Namun disinfektan sederhana dapat membunuh virus tersebut sehingga tidak mungkin menginfeksi orang lagi. Dan membiasakan cuci tangan dengan air dan sabun, atau hand-rub berbasis alkohol, serta hindari menyentuh mata, mulut atau hidung (segitiga wajah) lebih efektif melindungi diri. Alasan pemberian brosur dan masker ini juga dikaitkan dengan masih pentingnya pelaksanaan pendidikan kesehatan dengan teknik emotional demonstration secara langsung, mengingat pada saat pendidikan dilakukan dapat menggugah emotional masyarakat sebagai peserta didik dengan demonstrasi yang dilakukan.

Beberapa cara yang bisa dilakukan untuk mencegah tertularnya virus ini adalah: 1)Menjaga kesehatan dan kebugaran agar stamina tubuh tetap prima dan sistem imunitas / kekebalan tubuh meningkat. Mencuci tangan secara teratur menggunakan air dan sabun atau handrub berbasis alkohol. Mencuci tangan sampai bersih selain dapat membunuh virus yang mungkin ada di tangan kita, tindakan ini juga merupakan salah satu tindakan yang mudah dan murah. Sekitar $98 \%$ penyebaran penyakit bersumber dari tangan. Karena itu, menjaga kebersihan tangan adalah hal yang sangat penting. 2) Ketika batuk dan bersin, tutup hidung dan mulut Anda dengan tisu atau lengan atas bagian dalam (bukan dengan telapak tangan). 3) Hindari kontak dengan orang lain atau bepergian ke tempat umum. 4) Hindari menyentuh mata, hidung dan mulut (segitiga wajah). Tangan menyentuh banyak hal yang dapat terkontaminasi virus. Jika kita menyentuh mata, hidung dan mulut dengan tangan yang terkontaminasi, maka virus dapat dengan mudah masuk ke tubuh kita. 5) Gunakan masker penutup mulut dan hidung ketika Anda sakit atau saat berada di tempat umum. 6) Buang tisu dan masker yang sudah digunakan ke tempat sampah dengan benar, lalu cucilah tangan Anda. 7) Menunda perjalanan ke daerah/ negara dimana virus ini ditemukan. 8) Hindari bepergian ke luar rumah saat Anda merasa kurang sehat, terutama jika Anda merasa demam, batuk, dan sulit bernapas. Segera hubungi petugas kesehatan terdekat, dan mintalah bantuan mereka. Sampaikan pada petugas jika dalam 14 hari sebelumnya Anda pernah melakukan perjalanan terutama ke negara terjangkit, atau pernah kontak erat dengan orang yang 
memiliki gejala yang sama. Ikuti arahan dari petugas kesehatan setempat. 9) Selalu pantau perkembangan penyakit COVID-19 dari sumber resmi dan akurat.

Program pembinaan masyarakat dengan melakukan sosialisasi ini mempunyai tujuan yang baik sesuai dengan program pemerintah dalam mengatasi pandemi covid 19 saat ini, yaitu dengan memutus rantai penyebaran.

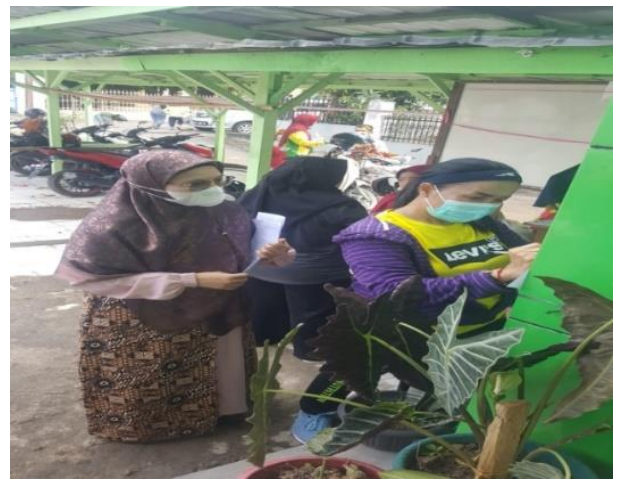

Gambar 1. Kegiatan pengabmas

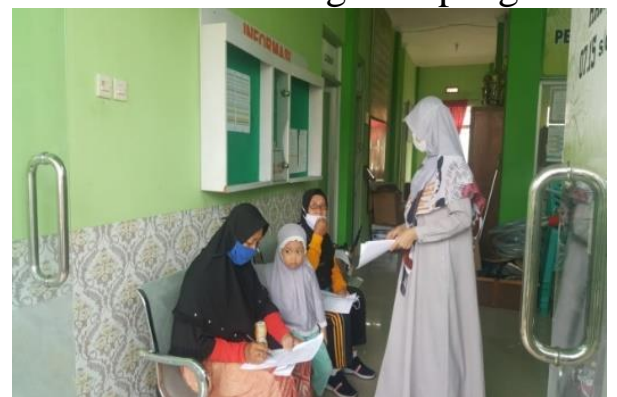

Gambar 2. Kegiatan pengabmas

\section{KESIMPULAN DAN SARAN}

\section{Kesimpulan}

Kegiatan yang dilakukan yaitu berupa sosialisasi tentang pemilihan dan penggunaan masker yang baik dan benar untuk mencegah masunya virus penyebab penyakit covid 19, dengan cara bertatap muka langsung dengan masyarakat namun tetap mengikuti protokol keseshatan pencegahan covid 19.Sosialisasi dilakukan dengan cara penyuluhan atau memberikan pendidikan kesehatan prilaku yang benar untuk mencegah penularan covid dengan memilih dan menggunakan masker yang baik dan benar. Penyebaran brosur, menunjukkan beberapa jenis masker yang dapat mencegah covid 19dan cara penggunaannya. Masyarakat menyambut baik program sosialisasi ini dan berharap program pendidikan kesehatan pada masyarakat ini dapat dibuat berkelanjutan sesuai dengan masalah-masalah kesehatan yang ada di masyarakat.

\section{Saran}

Sebaiknya dibuat program berkelanjutan di setiap kelurahan terutama kelurahan dengan lokasi wilayah yang beresiko terjadinya masalah kesehatan di masyarakat. Penting dilakukan tindakan langsung untuk menjelaskan, dan mengingatkan pada masyarakat betapa berisikonya kesehatan diri jika sampai terpapar virus covid 19.

\section{UCAPAN TERIMA KASIH}

Ucapan terimakasih ditujukan untuk sekolah Tinggi Ilmu Kesehatan Baiturrahim Jambi yang telah memberikan dukungan moril dan materil serta kemudahan untuk terlaksananya kegiatan ini. Selanjutnya ucapan terimakasih juga ditujukan oleh pihak Kelurahan Talang Banjar beserta masyarakat yang telah memfasilitasi dan memberikan dukungan moril bagi pelaksanaan kegiatan ini dilokasi pengabdian.

\section{DAFTAR PUSTAKA}

GAIN (Global Alliance For Improved Nutrition, dan Kemenkes RI. Modul Emotional demonstration.

Notoadmodjo, Soekidjo. 2012. Promosi Kesehatandan Ilmu Perilaku.PT RinekaCipta. Jakarta.

Pieter, HZ. 2011. Pengantar Psikopatologi Untuk Keperawatan. Jakarta: Kencana Media Grup.

Promkes Kesehatan RI \& Perhimpunan Dokter Paru Indonesia

https://stoppneumonia.id/informasi-tentangvirus-corona-novel-coronavirus 